\title{
Klasifikasi Tipologi Zona Perwilayahan Wilayah Peri-Urban di Kecamatan Kartasura, Kabupaten Sukoharjo
}

\author{
Nela Agustin Kurnianingsih ${ }^{1}$ \\ Magister Pembangunan Wilayah dan Kota \\ Universitas Diponegoro, Semarang, Indonesia
}

\begin{abstract}
Abstrak: Wilayah Peri-Urban yang hadir sebagai zona transisi antara kota dan desa telah memberikan ragam wilayah baru yang memiliki karakteristik yang unik. Keunikan perkembangan yang membuat WPU memiliki sifat kekotaan dengan kepadatan yang tinggi dan aktivitas yang beraneka ragam dan ramai, dan juga keunikan sifat pedesaan yang tetap hadir dengan bercirikan sektor pertanian. Sifat kekotaan dan pedesaan yang dimiliki WPU timbul sebagai dampak perkembangan kota di sekitarnya. Kecamatan Kartasura merupakan salah satu anggota Wilayah Peri-Urban yang muncul sebagai bentuk nyata dampak perkembangan Kota Surakarta dalam aspek fisik, sosial, dan ekonomi. Kemampuan Kota Surakarta yang mampu mempengaruhi perkembangan Kecamatan Kartasura ternyata dapat memunculkan sifat kekotaan di sebagian wilayah desa. Di samping itu, perkembangan Kecamatan Kartasura juga disinyalir berkat historis yang tinggi sebagai salah satu pusat kerajaan Islam di Jawa Tengah dan menjadi cikal bakal Surakarta. Namun dengan perkembangan yang tidak merata, menimbulkan adanya fenomena keeksistensian sifat pedesaan sebagai karakteristik unik WPU. Untuk secara nyatanya, diketahui bahwa, meskipun terjadi alih fungsi lahan pertanian tiap tahunnya sebagai bentuk perkembangan kekotaan, sektor pertanian Kecamatan Kartasura masih tetap bertahan dengan dibuktikan melalui peningkatan PDRB di sektor ini. Keunikan sifat kekotaan yang berpadu dengan sifat pedesaan di WPU Kecamatan Kartasura ini menimbulkan suatu pertanyaan, "bagaimana klasifikasi zona perwilayah yang terbentuk di Wilayah Peri-Urban tersebut, tentu saja jika dilihat dari aspek fisik, sosial, dan ekonomi?" Melalui pertanyaan tersebut, penelitian ini dibuat untuk melakukan identifikasi tingkat urbanisasi suatu desa dalam aspek fisik, sosial dan ekonomi yang ditujukkan dalam zona perwilayah WPU, meliputi zona peri-urban primer, zona peri-urban sekunder, dan zona rural peri-urban. Klasifikasi zona perwilayahan dengan analisis spasial yang memanfaatkan SIG ini mendapatkan hasil berupa tiga zona yang terdiri dari: peri-urban primer meliputi 2 desa/kelurahan dengan luas wilayah sebesar $265 \mathrm{Ha}$, periurban sekunder meliputi 8 desa dengan luas wilayah $1.368 \mathrm{Ha}$, dan rural peri-urban yang meliputi 2 desa dengan luas wilayah sebesar 290 Ha. Dari hasil klasifikasi ini sendiri ditemukan karakteristik WPU yang menjadi ciri khas Kecamatan Kartasura yang membedakan dengan wilayah peri-urban lainnya.
\end{abstract}

Kata Kunci: Fisik Sosial Ekonomi, Sifat Kekotaan dan Pedesaan, SIG, Wlayah Peri-Urban, Zona

Abstract: Pheri-Urban Zone comes as transition zone between rural and urban, have given something unique characteristic on region types. The growth makes pheri-urban zone have urban characteristic with high population density and heterogeneity of activities, and have

\footnotetext{
${ }^{1}$ Korespondensi Penulis: Magister Pembangunan Wilayah dan Kota, Universitas Diponegoro, Semarang Email: nela4kurnia@gmail.com
} 
rural characteristic with existence of agricultural sector. That does all arise as growth effect from urbancore. Kartasura Sub-District is one of pheri-urban zone, which arose as growth effect from Surakarta city on physic aspect, social aspect, and economic aspect. The growth of Surakarta city made some villages in Kartasura changed to urban ways. Beside of that, the growth of Kartasura Sub-District become urban area,was influenced by historical story, in long time ago Kartasura Sub-district was one of Islam Palace in Indonesia before was moved to Surakarta City. However, with no spread growth in Kartasura, could make existence of rural characteristic. For the proof, although in Kartasura occur land use change in agricultural sector, this sub-district had income increase in every year for this sector. Uniqueness of blend from urban ways and rural ways in Kartasura Sub-District made one research question, how is the classification of pheri-urban zone in Kartasura, absolutely is looked from physic, social and economic aspects? From that research question, this research was done to identification urbanization level for villages in Kartasura Sub-District into three pheri-urban zones: primary pheri-urban zone, secondary pheri-urban zone, and rural pheri-urban zone. This classification used spatial analysis with GIS. For the result, in Kartasura have three pheri-urban zones: 2 villages include primary pheri-urban zone with landmass is $265 \mathrm{Ha}, 8$ villages include secondary pheri-urban zone with landmass is $1.368 \mathrm{Ha}$ and 2 villages include rural pheriurban zone with landmass $290 \mathrm{Ha}$. from this research, was known some characteristic of pheri-urban zone in Kartasura, which can make different from the other pheri-urban zones.

Keywords: pheri-urban zone, zone, urban and rural ways, physic social economic, and GIS.

\section{Pendahuluan}

Kawasan peri-urban muncul sebagai zona transisi antara kota dengan desa. Dorongan perkembangan di perkotaan yang berciri padat terbangun dan desakan keeksistensian pedesaan yang lebih bercirikan sektor pertanian menjadikan keberadaan wilayah periurban sebagai salah satu tipe wilayah yang perlu diperhitungkan.

Perkembangan perkotaan yang memiliki keterbatasan lahan akhirnya memaksa untuk terjadinya pembangunan secara eksternal. Proses pembangunan eksternal akhirnya mendesak terjadinya perubahan fungsi lahan pada wilayah terdekatnya, yang sebelumnya lebih bercirikan sektor pedesaan. Dengan jangkauan perkembangan yang hanya pada batas tertentu, akhirnya membuat suatu wilayah seperti mengalami transisi dari kota menuju ke desa. Hal ini seperti yang dialami oleh Kecamatan Kartasura yang terpengaruh oleh Kota Surakarta sebagai urban core-nya.

Perkembangan pembangunan fisik di Kecamatan Kartasura yang terpengaruh oleh Kota Surakarta secara nyata, antara lain: Kantor Balai Sungai dan Balai Kehutanan Surakarta, Rumah Sakit Islam Surakarta, Universitas Muhammadiyah Surakarta, Kampus V Universitas Sebelas Maret (UNS), dan lain-lain yang mengambil kebanyakan lokasi di Desa pabelan yang berbatasan langsung dengan Kota Surakarta. Di sisi lain, menurut sejarahnya, ternyata Kecamatan Kartasura merupakan salah satu kerajaan Islam di Jawa dan menjadi cikal bakal dari Kasunanan Surakarta Hadiningrat. Oleh karena itu, kedua wilayah ini memiliki kekerabatan sejarah perkembangan fisik yang erat. Namun, perkembangan wilayah peri-urban terjadi transformasi bukan hanya pada aspek fisik saja. Melainkan juga pada aspek sosial ekonominya.

\section{Perumusan Masalah}

Mengenai transformasi aspek fisik, sosial, dan ekonomi Kecamatan Kartasura sebagai wilayah peri-urban dari Kota Surakarta, bisa dijelaskan bahwa terkait transformasi aspek fisik, terjadi perubahan fungsi lahan pertanian ke lahan terbangun yang cukup besar, yaitu 
564,6 Ha pada tahun 1998-2002 di Kecamatan Kartasura. Dan perubahan lahan tersebut selalu terjadi di tiap tahunnya hingga sekarang. Akibatnya, banyak lahan pertanian yang tergeser oleh posisi lahan terbangun.

Meskipun, padat terbangun lebih bercirikan sebagai wilayah perkotaan karena sebagai lokasi aktivitas yang heterogen, kenyataannya yang ditemui di Kecamatan Kartasura, pada data PDRB dijelaskan bahwa terjadi peningkatan pendapatan sektor pertanian di setiap tahunnya, yaitu dari angka Rp 82.906.930.000 di tahun 2008, menjadi Rp 101.644.740.000 di tahun 2009. Dengan demikian, bisa dikatakan bahwa perkembangan pedesaan di Kecamatan ini masih baik.

Dengan melihat transformasi fisik, sosial, ekonomi yang terjadi dan dibandingkan dengan penelitian dari beberapa tokoh, seperti Singh, Desrainy, et al, Hadi Sabari Yunus dan lainnya, bisa disimpulkan bahwa pengklasifikasian wilayah peri-urban harus bisa menilai dengan melihat ketiga aspek tersebut. Oleh karena itu, penelitian ini disusun untuk menjawab pertanyaan tentang bagaimanakah klasifikasi zona perwilayahan WPU yang terbentuk di desa-desa Kecamatan Kartasura, apabila ditinjau berdasarkan karakteristik Wilayah Peri-Urban (WPU) dalam aspek fisik, sosial, dan ekonomi?

\section{Tujuan dan Sasaran}

Penelitian ini dilakukan dengan tujuan untuk mengklasifikasikan zona perwilayahan WPU yang terbentuk atas desa/kelurahan di Kecamatan Kartasura berdasarkan karakteristik Wilayah Peri-Urban terkait fisik, sosial dan ekonomi masyarakat yang nantinya bisa dijadikan sebagai acuan kesesuaian arahan pemanfaatan ruang di Kecamatan Kartasura atas produk perencanaan yang ada. Dalam upaya untuk mewujudkan tujuan tersebut, maka diambil beberapa sasaran, yaitu:

a. Mengidentifikasi data-data Kecamatan Kartasura yang dibutuhkan dalam penelitian.

b. Mengidentifikasi variabel-variabel yang akan digunakan untuk melakukan pengklasifikasian zona perwilayahan WPU terkait aspek fisik, sosial dan ekonomi.

c. Mengklasifikasi zona perwilayahan di Kecamatan Kartasura berdasarkan tiap variabel yang diambil.

d. Menganalisis klasifikasi zona perwilayahan WPU yang terbentuk dengan overlay dan pembobotan dari beberapa peta analisis yang didapat sebelumnya.

\section{Metode Penelitian}

Pada penelitian proses klasifikasi ini, diperlukan metode penelitian kuantitatif dengan membandingkan data dengan kriteria klasifikasi yang didapat dari penyesuaian teori dari beberapa tokoh, seperti Desrainy, et all, Singh, dan Hadi Sabari Yunus. Selain itu, juga menggunakan beberapa kriteria kebijakan dari lembaga pemerintah, lihat Tabel 1. Untuk klasifikasi zona WPU jumlah kelas menyesuaikan dengan Singh (2011) yang terdiri dari: peri-urban primer, peri-urban sekunder, dan rural peri-urban.

Terkait metode penelitian yang dipakai saat proses klasifikasi dan analisis, penelitian ini akan menerapkan analisis deskriptif kuantitatif dengan bantuan SIG yang berfungsi dalam proses mapping data untuk klasifikasi atas tiap variable yang akan dipakai, lihat Gambar 1. Mapping data akan dilakukan dengan membandingkan kriteria klasifikasi tiap zona WPU dengan data yang ada lalu membagi desa ke dalam zona yang sesuai perbandingan.

\section{Tabel 1. Kriteria Klasifikasi dan Metode Skoring Terhadap WPU Kecamatan Kartasura}




\begin{tabular}{|c|c|c|c|c|c|c|c|c|}
\hline \multirow{3}{*}{ No. } & \multirow{3}{*}{ Variabel } & \multicolumn{6}{|c|}{ Karakteristik } & \multirow{3}{*}{ Sumber Kriteria } \\
\hline & & \multicolumn{2}{|l|}{ Peri-Urban Primer } & \multicolumn{2}{|c|}{ Peri-Urban Selunder } & \multicolumn{2}{|c|}{ Rural Peri-Urban } & \\
\hline & & Kriteria & Skor & Kriteria & Skor & Kriteria & Skor & \\
\hline 1. & \multicolumn{8}{|l|}{ Aspelk Fisilk } \\
\hline a. & penggunaan lahan & $\begin{array}{c}>50 \% \text { lahan non-agraris atan } \\
<50 \% \text { lahan agraris }\end{array}$ & 2 & - & - & $\begin{array}{l}\geq 50 \% \text { lahan non-agraris } \\
\text { atan } \leq 50 \% \text { lahan agraris }\end{array}$ & 1 & $\begin{array}{c}\text { Desrainy, et all (2010), } \\
\text { Pryor (1971, dalam Yunus, } \\
2008)\end{array}$ \\
\hline b. & Sarana Kesehatan & Rasio kesehatan tinggi & 3 & Rasio kesehatan sedang & 2 & Rasio kesehatan rendah & 1 & $\begin{array}{l}\text { Desrainy, et all dengan } \\
\text { lriteria PP no } 129 \mathrm{Th} 2000\end{array}$ \\
\hline \multirow[t]{4}{*}{ c. } & \multirow{4}{*}{$\begin{array}{l}\text { Sarana pendidikan: } \\
\text { SD } \\
\text { SMP } \\
\text { SMA } \\
\text { Perguruan tinggi }\end{array}$} & \multirow{4}{*}{$\begin{array}{c}\text { Rasio sarana pendidikan } \\
\text { tinggi }\end{array}$} & 3 & \multirow{4}{*}{$\begin{array}{c}\text { Rasio sarana pendidikan } \\
\text { sedang }\end{array}$} & 2 & \multirow{4}{*}{$\begin{array}{l}\text { Rasio sarana pendidikan } \\
\text { rendah }\end{array}$} & 1 & \multirow{4}{*}{$\begin{array}{l}\text { Desrainy, et all dan Singh } \\
\text { (2011) dengan lkriteria PP } \\
\text { no } 129 \mathrm{Th} 2000\end{array}$} \\
\hline & & & 3 & & 2 & & 1 & \\
\hline & & & 3 & & 2 & & 1 & \\
\hline & & & 3 & & 2 & & 1 & \\
\hline 2. & \multicolumn{8}{|l|}{ Aspek Sosial } \\
\hline a. & Kepadatan penduduk & $\begin{array}{c}\geq 5000 \mathrm{jiww} / \mathrm{km} 2 \text { (tinglkat } \\
\text { desa) }\end{array}$ & 3 & $\begin{array}{c}\geq 3000 \mathrm{jiwg} / \mathrm{km} 2 \text { hingga }< \\
5000 \mathrm{jiws} / \mathrm{Km} 2 \text { (desa) }\end{array}$ & 2 & $\begin{array}{l}\geq 1000 \mathrm{jiwa} / \mathrm{km} 2 \text { hingga } \\
<3000 \mathrm{jiws} / \mathrm{km} 2 \text { (desa) }\end{array}$ & 1 & Singh (2011) \\
\hline b. & $\begin{array}{l}\text { Tingkat Kelahiran } \\
\text { Pendudul: }\end{array}$ & CBR tinggi & 3 & CBR sadang & 2 & CBR rendah & 1 & Desrainy, et all (2010) \\
\hline c. & Tinglkat kematian penduduk & $\mathrm{CDR}$ rendsh & 3 & CDR seding & 2 & CDR tinggi & 1 & Desrainy, et all (2010) \\
\hline d. & $\begin{array}{l}\text { Rasio beban tanggunan } \\
\text { (dilihat dari jumlah } \\
\text { masyarakst usia produltif) }\end{array}$ & $\begin{array}{c}\text { Rasio beban tanggungan } \\
\text { besar }(<25 \%)\end{array}$ & 3 & $\begin{array}{l}\text { Rasio beban tanggungan } \\
25 \% \text { hingga } 50 \%\end{array}$ & 2 & $\begin{array}{c}\text { Rasio beban tanggungan } \\
>50 \%\end{array}$ & 1 & $\begin{array}{l}\text { Desrainy, et all (2010) dan } \\
\text { Kriteria dalam Profil desa }\end{array}$ \\
\hline e. & $\begin{array}{l}\text { Kualitas SDM (dilihat } \\
\text { melalui litersai penduduk } \\
\text { semua usia dibanding total } \\
\text { penduduk) }\end{array}$ & melek huruf tinggi & 3 & melelk huruf sadang & 2 & melelk huruf rendah & 1 & $\begin{array}{l}\text { Desrainy, et all dan Singh } \\
\text { (2011) dengan kategori } \\
\text { BPS }\end{array}$ \\
\hline$f$ & Heterogenitas & $\geq 50 \%$ pendudul datang & 3 & $<50 \%$ pendudulk datang & 2 & $\begin{array}{l}\text { kecenderungan } \\
\text { penduduk lebih } \\
\text { homogeny/asli }\end{array}$ & 1 & Desrainy, et all (2010) \\
\hline 3. & \multicolumn{8}{|l|}{ Aspek Elkonomi } \\
\hline a. & $\begin{array}{l}\text { Proporsi keluarga pra } \\
\text { sejahtera dengan sajahtera }\end{array}$ & $\begin{array}{l}\text { Keluarga Pra Sejahtera } \\
\text { rendah }\end{array}$ & 3 & $\begin{array}{l}\text { Keluarga Pra Sejahtera } \\
\text { Sedang }\end{array}$ & 2 & $\begin{array}{c}\text { Keluarga Pra Sejahtera } \\
\text { Tinggi }\end{array}$ & 1 & $\begin{array}{l}\text { Gabungan Dasrainy, et all } \\
\text { dan kebijalsan BPS }\end{array}$ \\
\hline b. & $\begin{array}{l}\text { Proporai Mata Pencaharian } \\
\text { bidang non-pertanian }\end{array}$ & $\begin{array}{l}\geq+3 \text { SD (Rata-rata jumlah } \\
\text { pekerja non pertanian = } \\
\text { prosentase pekerja non- } \\
\text { pertanian terendah + } \\
\text { ISD) }\end{array}$ & 3 & $\begin{array}{c}z+2 \text { SD hingga }<+3 \text { SD } \\
\text { (Rata-rata jumlah pelseja } \\
\text { non pertanian }=\text { prosentase } \\
\text { pekerja non-pertanism } \\
\text { terendah }+ \text { 1SD) }\end{array}$ & 2 & $\begin{array}{c}<+2 \text { SD (Rata-Rata } \\
\text { jumlah pekerja non- } \\
\text { pertanian= prosentase } \\
\text { pekerja non-pertanian } \\
\text { terendah }+1 \mathrm{SD})\end{array}$ & 1 & Singh (2011) \\
\hline c. & $\begin{array}{l}\text { Proporsi Mata Pencaharian } \\
\text { bidang pertanian }\end{array}$ & $\begin{array}{l}20 \%-40 \% \text { pendudul: bermata } \\
\text { pencaharian seltor pertanian }\end{array}$ & 3 & $\begin{array}{c}40 \%-60 \% \text { pendudulk } \\
\text { bermata pencaharian sektor } \\
\text { pertanian }\end{array}$ & 2 & $\begin{array}{l}>60 \% \text { pendudul: } \\
\text { bermata pencaharian } \\
\text { aektor pertanian }\end{array}$ & 1 & Singh (2011) \\
\hline & TOTAL & & 44 & & 28 & & 15 & \\
\hline
\end{tabular}

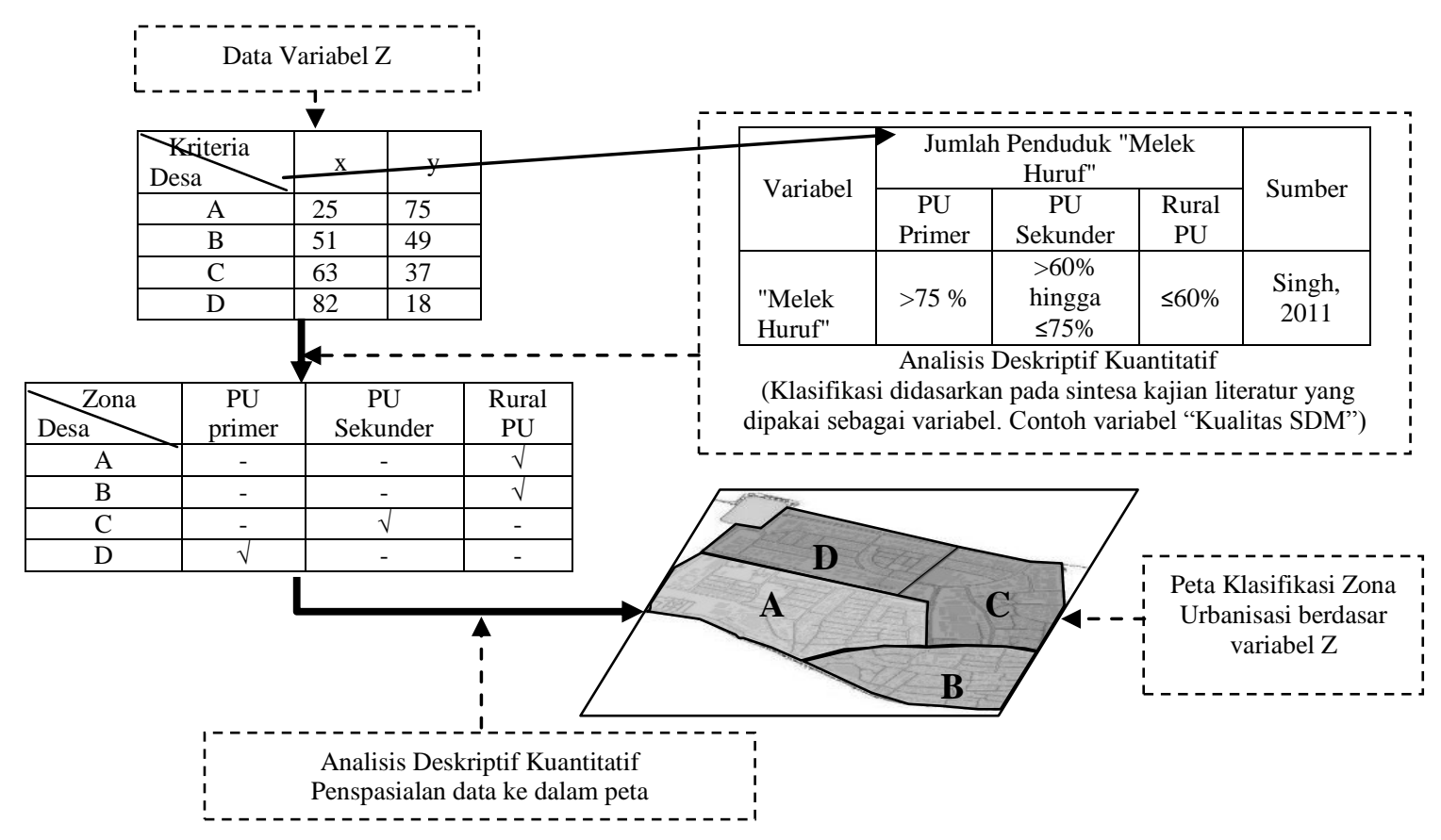

\section{Gambar 1. Proses Identifikasi Klasifikasi Zona Perwilayahan pada Wilayah Peri Urban Berdasar Tiap Variabel dalam Aspek Fisik, Sosial, dan Ekonomi}


Sedangkan untuk analisis akhir guna untuk mengetahui hasil klasifikasi berdasar tiga aspek, maka akan dilakukan dengan menggunakan overlay dan metode pembobotan, lihat Gambar 2. Pada metode pembobotan ini akan dilakukan dengan skoring, lihat Tabel 1.

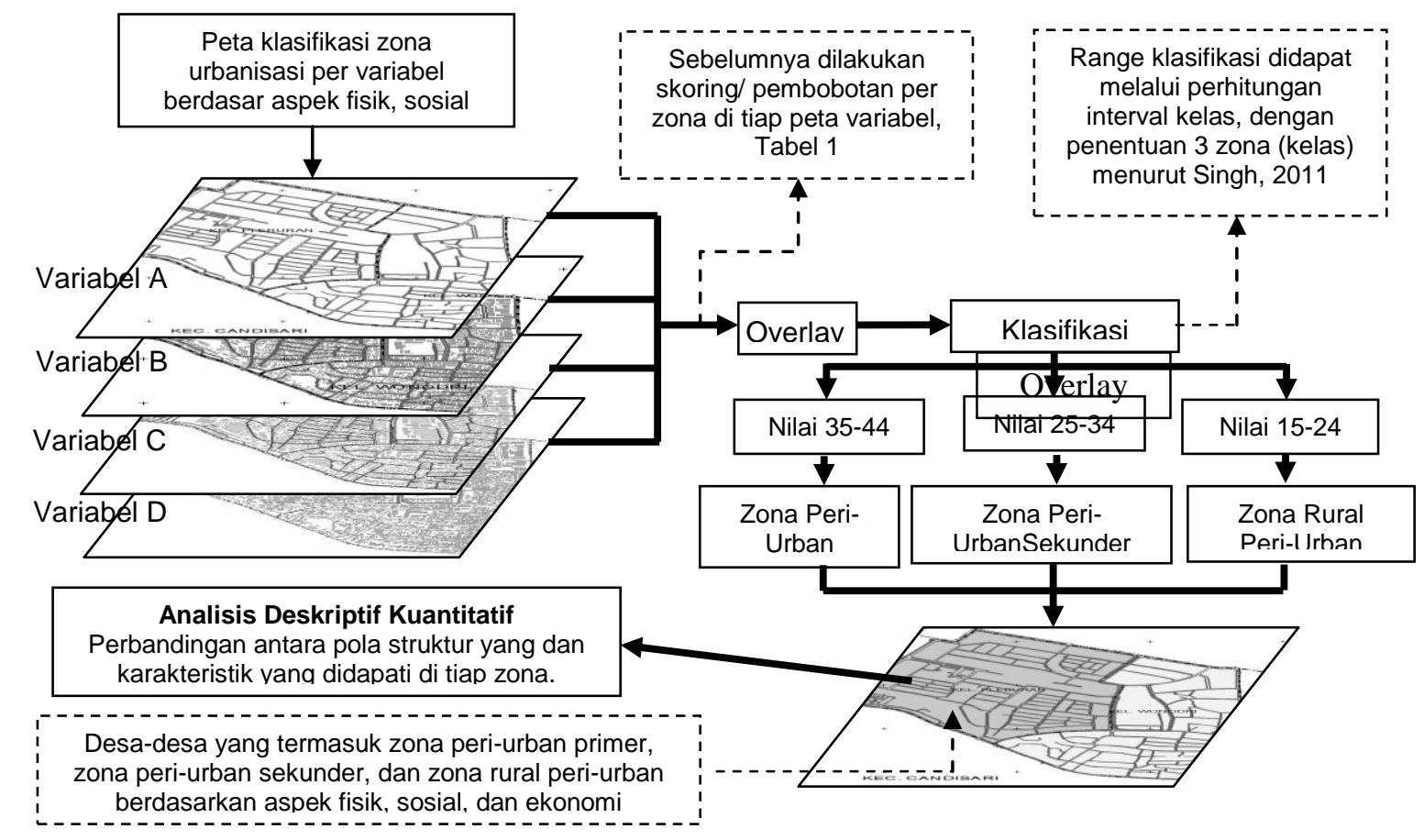

\section{Gambar 2. Proses Analisis Klasifikasi Zona Perwilayahan WPU berdasar Aspek Fisik, Sosial, dan Ekonomi}

\section{Klasifikasi Wilayah Peri-Urban Kecamatan Kartasura Berdasar Aspek Fisik, Sosial, dan Ekonomi}

Seperti yang dijelaskan dalam bahasan perumusan masalah, bahwa untuk pproses pengklasifikasian zona WPU Kecamatan Kartasura akan dilihat dari tiga aspek yang berbeda, yaitu aspek fisik, aspek sosial, dan aspek ekonomi. Oleh karena itu, dengan membandingkan data sekunder dengan kriteria pada Tabel 1, maka didapatkan hasil klasifikasi sebagai berikut

\section{Aspek Fisik}

Pada aspek fisik, klasifikasi zona WPU akan dilakukan dengan penentuan variable yang terdiri dari: variable penggunaan lahan pertanian dan non-pertanian, variable sarana kesehatan dan variable sarana pendidikan. Untuk variable sarana pendidikan akan terbagi atas SD, SMP, SMA dan Perguruan Tinggi. Hal ini karena kriteria yang menyebutkan klasifikasi lebih berdasar pada rasio sarana pendidikan, dan untuk perhitungan rasio sarana sesuai PP No 129 tahun 2000, perhitungan rasio sesuai tingkat pendidikan dan jangka umur penduduk. 
Tabel 2. Klasifikasi Berdasar Aspek Fisik

\begin{tabular}{c|c|c|c|c|c|c|c}
\hline \multirow{2}{*}{ No } & \multirow{2}{*}{$\begin{array}{c}\text { Desa/Kelu- } \\
\text { rahan }\end{array}$} & \multirow{2}{*}{$\begin{array}{c}\text { Penggunaan } \\
\text { Lahan }\end{array}$} & Kesehatan & \multicolumn{5}{|c}{ Sarana Pendidikan } \\
\cline { 5 - 7 } 1 & Ngemplak & Rural PU & PU Primer & $\begin{array}{c}\text { PU } \\
\text { Sekunder }\end{array}$ & Rural PU & Rural PU & Rural PU \\
\hline 2 & Gumpang & PU Primer & $\begin{array}{c}\text { PU } \\
\text { Sekunder }\end{array}$ & $\begin{array}{c}\text { PU } \\
\text { Sekunder }\end{array}$ & Rural PU & Rural PU & Rural PU \\
\hline 3 & Makamhaji & PU Primer & $\begin{array}{c}\text { PU } \\
\text { Sekunder }\end{array}$ & PU Primer & Rural PU & Rural PU & Rural PU \\
\hline 4 & Pabelan & PU Primer & PU Primer & PU Primer & $\begin{array}{c}\text { PU } \\
\text { Sekunder }\end{array}$ & PU Primer & PU Primer \\
\hline 5 & Ngadirejo & PU Primer & Rural PU & Rural PU & Rural PU & Rural PU & Rural PU \\
\hline 6 & Kartasura & PU Primer & Rural PU & PU Primer & PU Primer & PU Primer & Rural PU \\
\hline 7 & Pucangan & Rural PU & Rural PU & $\begin{array}{c}\text { PU } \\
\text { Sekunder }\end{array}$ & Rural PU & $\begin{array}{c}\text { PU } \\
\text { Sekunder }\end{array}$ & Rural PU \\
\hline 8 & Kertonatan & Rural PU & Rural PU & Rural PU & Rural PU & Rural PU & Rural PU \\
\hline 9 & Wirogunan & Rural PU & PU Primer & $\begin{array}{c}\text { PU } \\
\text { Sekunder }\end{array}$ & Rural PU & $\begin{array}{c}\text { PU } \\
\text { Sekunder }\end{array}$ & Rural PU \\
\hline 10 & Ngabeyan & Rural PU & $\begin{array}{c}\text { PU } \\
\text { Sekunder }\end{array}$ & Rural PU & Rural PU & $\begin{array}{c}\text { PU } \\
\text { Sekunder }\end{array}$ & Rural PU \\
\hline 11 & Singopuran & PU Primer & Rural PU & Rural PU & Rural PU & Rural PU & Rural PU \\
\hline 12 & Gonilan & PU Primer & Rural PU & Rural PU & Rural PU & Rural PU & Rural PU \\
\hline
\end{tabular}

$\mathrm{PU}=$ Peri-urban

Melalui klasifikasi beberapa variable aspek fisik, maka didapatkan hasil seperti Tabel 2. Pada tabel 2 diketahui bahwa untuk variable penggunaan lahan memiliki hasil 7 desa termasuk peri-urban primer dan 5 desa rural peri-urban. Dengan demikian bisa dikatakan bahwa cukup banyak desa di Kecamatan Kartasura yang berkarakteristik perkotaan dengan artian komposisi lahan pertanian lebih sedikit dibanding lahan terbangun. Sedangkan terkait variable kesehatan hanya ada 2 desa bersifat primer dalam artian pemenuhan fasilitas kesehatan masih sedikit karena diindikasikan oleh Desrainy, et all (2010) bahwa perkotaan akan memiliki sarana kesehatan yang memadai. Dan untuk sarana pendidikan, secara umum semakin tinggi jenjang pendidikan, semakin sedikit desa yang bersifat primer.

Untuk melihat klasifikasi berdasar aspek fisik, maka bisa dilihat dari Gambar 3. Pengklasifikasian aspek fisik dilakukan dengan overlay dan pebobotan dari hasil klasifikasi per variable dalam aspek fisik. Melalui Gambar 3. apabila dikaitkan dengan Kota Surakarta (urban core Kecamatan Kartasura) ternyata hanya mampu mempengaruhi Desa Pabelan yang berbatasan langsung dan berada pada jalan kolektor utama. Untuk Kelurahan Kartasura sendiri bisa dikatakan lebih berkembang karena aksesibilitas yang ada dan lokasi kelurahan yang dilalui oleh Jalan Solo-Semarang dan Jalan Solo-Yogyakarta dimungkinkan sebagai salah satu faktor adanya pembangunan kelengkapan fasilitas. Selain itu, juga sejarah yang menempatkan kelurahan Kartasura sebagai pusat kota sejak Kerajaan Kartasura Hadiningrat dianggap berpengaruh pada pertumbuhan fisik di kelurahan ini. 


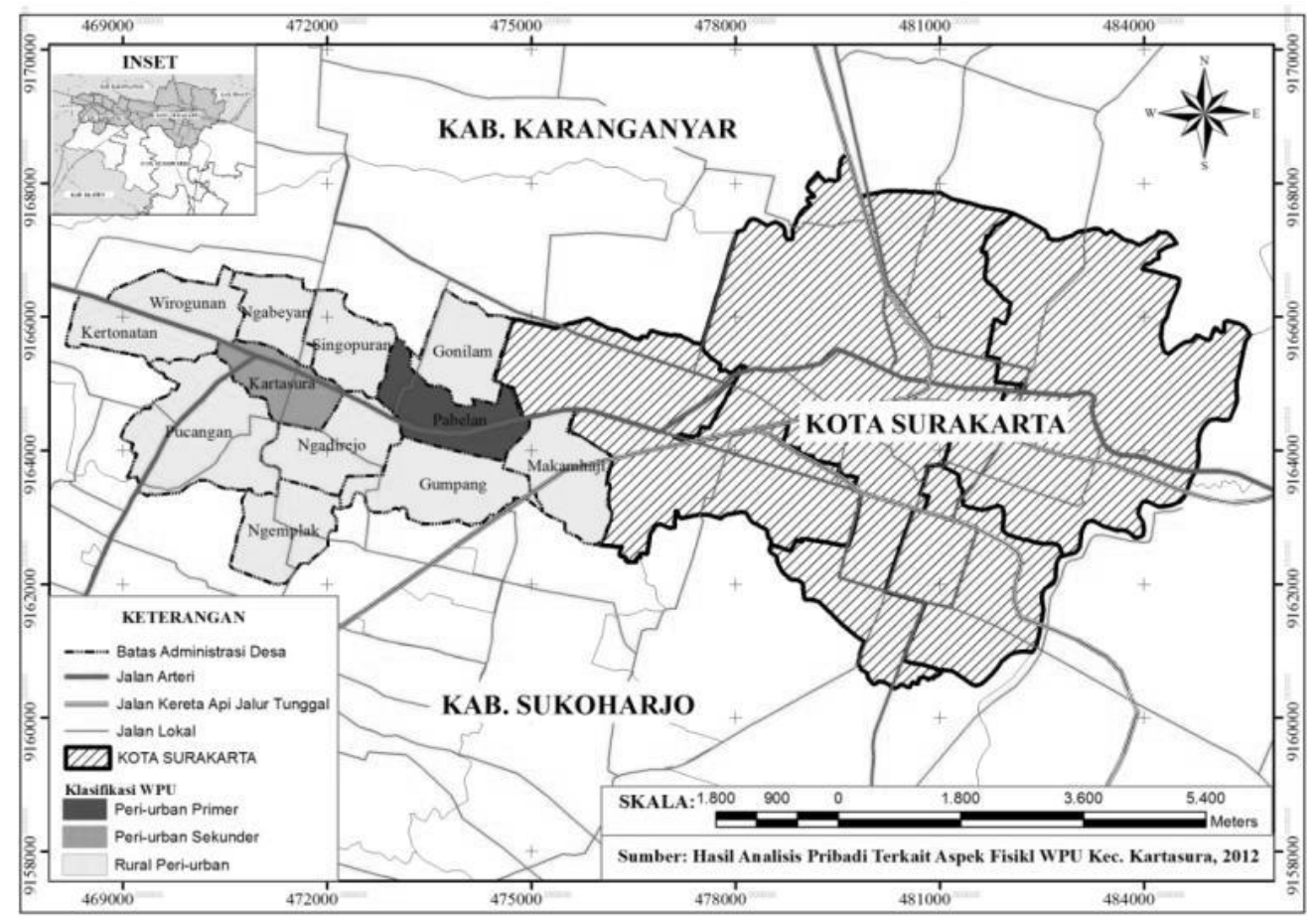

Gambar 3. Peta Tipologi Zona WPU Kecamatan Kartasura Berdasar Aspek Fisik

\section{Aspek Sosial}

Pada aspek sosial, klasifikasi akan dilakukan dengan menggunakan variable kepadatan penduduk, CBR dan CDR, rasio beban tanggungan yang lebih diindikasikan dari proporsi penduduk usia produktif, kualitas SDM yang dihitung dari literasi penduduk, dan heterogenitas yang dihitung dari penduduk datang. Melalui kriteria pada Tabel 1 dan data, untuk klasifikasi WPU Kecamatan Kartasura pada tiap variabelnya dapat dilihat melalui Tabel 3.

Tabel 3.Klasifikasi Berdasar Aspek Sosial

\begin{tabular}{|r|l|c|c|c|c|c|c|}
\hline No & $\begin{array}{c}\text { Desa/ } \\
\text { Kelurahan }\end{array}$ & $\begin{array}{c}\text { Kepadatan } \\
\text { Penduduk }\end{array}$ & CBR & CDR & $\begin{array}{c}\text { Rasio Beban } \\
\text { Tanggungan }\end{array}$ & Kualitas SDM & Heterogenitas \\
\hline 1 & Ngemplak & Rural PU & PU Primer & PU Primer & Rural PU & Rural PU & PU Sekunder \\
\hline 2 & Gumpang & PU Primer & $\begin{array}{c}\text { PU } \\
\text { Sekunder }\end{array}$ & $\begin{array}{c}\text { PU } \\
\text { Sekunder }\end{array}$ & PU Sekunder & PU Sekunder & PU Sekunder \\
\hline 3 & Makamhaji & PU Primer & Rural PU & Rural PU & Rural PU & PU Sekunder & PU Sekunder \\
\hline 4 & Pabelan & PU Primer & $\begin{array}{c}\text { PU } \\
\text { Sekunder }\end{array}$ & Rural PU & PU Sekunder & PU Primer & PU Sekunder \\
\hline 5 & Ngadirejo & PU Primer & Rural PU & PU Primer & Rural PU & PU Sekunder & PU Sekunder \\
\hline 6 & Kartasura & PU Primer & PU Primer & Rural PU & PU Primer & PU Primer & PU Sekunder \\
\hline 7 & Pucangan & PU Primer & $\begin{array}{c}\text { PU } \\
\text { Sekunder }\end{array}$ & Rural PU & Rural PU & PU Primer & PU Sekunder \\
\hline 8 & Kertonatan & PU Sekunder & $\begin{array}{c}\text { PU } \\
\text { Sekunder }\end{array}$ & Rural PU & Rural PU & PU Sekunder & PU Sekunder \\
\hline 9 & Wirogunan & PU Sekunder & Rural PU & $\begin{array}{c}\text { PU } \\
\text { Sekunder }\end{array}$ & Rural PU & Rural PU & PU Sekunder \\
\hline
\end{tabular}


Klasifikasi Tipologi Zona Perwilayahan Wilayah Peri-Urban di Kecamatan Kartasura, Kabupaten Sukoharjo

\begin{tabular}{|c|l|c|c|c|c|c|c|}
\hline No & $\begin{array}{c}\text { Desa/ } \\
\text { Kelurahan }\end{array}$ & $\begin{array}{c}\text { Kepadatan } \\
\text { Penduduk }\end{array}$ & CBR & CDR & $\begin{array}{c}\text { Rasio Beban } \\
\text { Tanggungan }\end{array}$ & Kualitas SDM & Heterogenitas \\
\hline 10 & Ngabeyan & PU Sekunder & Rural PU & PU Primer & Rural PU & Rural PU & PU Sekunder \\
\hline 11 & Singopuran & PU Sekunder & Rural PU & PU Primer & PU Sekunder & PU Primer & PU Sekunder \\
\hline 12 & Gonilan & Rural PU & $\begin{array}{c}\text { PU } \\
\text { Sekunder }\end{array}$ & PU Primer & Rural PU & Rural PU & PU Sekunder \\
\hline
\end{tabular}

$\mathrm{PU}=$ Peri-urban

Pada Tabel 3, dapat diketahui bahwa untuk klasifikasi WPU Kecamatan Kartasura atas data sekunder tahun pertengahan 2011, zona peri-urban primer mendominasi pada klasifikasi dengan variable kepadatan penduduk. Seperti yang dijelaskan oleh Singh (2011) bahwa sifat perkotaan akan ditunjukkan melalui jumlah kepadatan penduduknya yang tinggi. Oleh karena itu, bisa dikatakan kepadatan di Kecamatan ini pada umumnya tinggi dengan lebih bercirikan pada perkotaan. Sedangkan zona peri-urban sekunder lebih mendominasi pada variable kualitas SDM dan heterogenitas. Hal ini mengindikasikan bahwa tingkat literasi penduduk Kecamatan Kartasura sudah berada pada kategori cukup bagus karena dijelaskan oleh Singh (2011) bahwa wilayah yang bercirikan kea rah perkotaan akan memiliki tingkat literasi (melek huruf) yang cukup tinggi dibanding di desa. Dan pada heterogenitas yang menghasilkan satu klasifikasi, yaitu peri-urban sekunder menjelaskan bahwa proporsi pendatang di tiap desa hampir sama. Sedangkan rural periurban lebih mendominasi pada CDR dan CBR, dimana kedua vaiabel ini memiliki hubungan dengan ketersediaan fasilitas kesehatan. Dengan demikian, mengindikasikan bahwa pada Kecamatan Kartasura terjadi ketidakmerataan fasilitas kesehatan yang berakibat pada rendahnya CBR dan tingginya CDR pada desa/kelurahan di Kecamatan Kartasura.

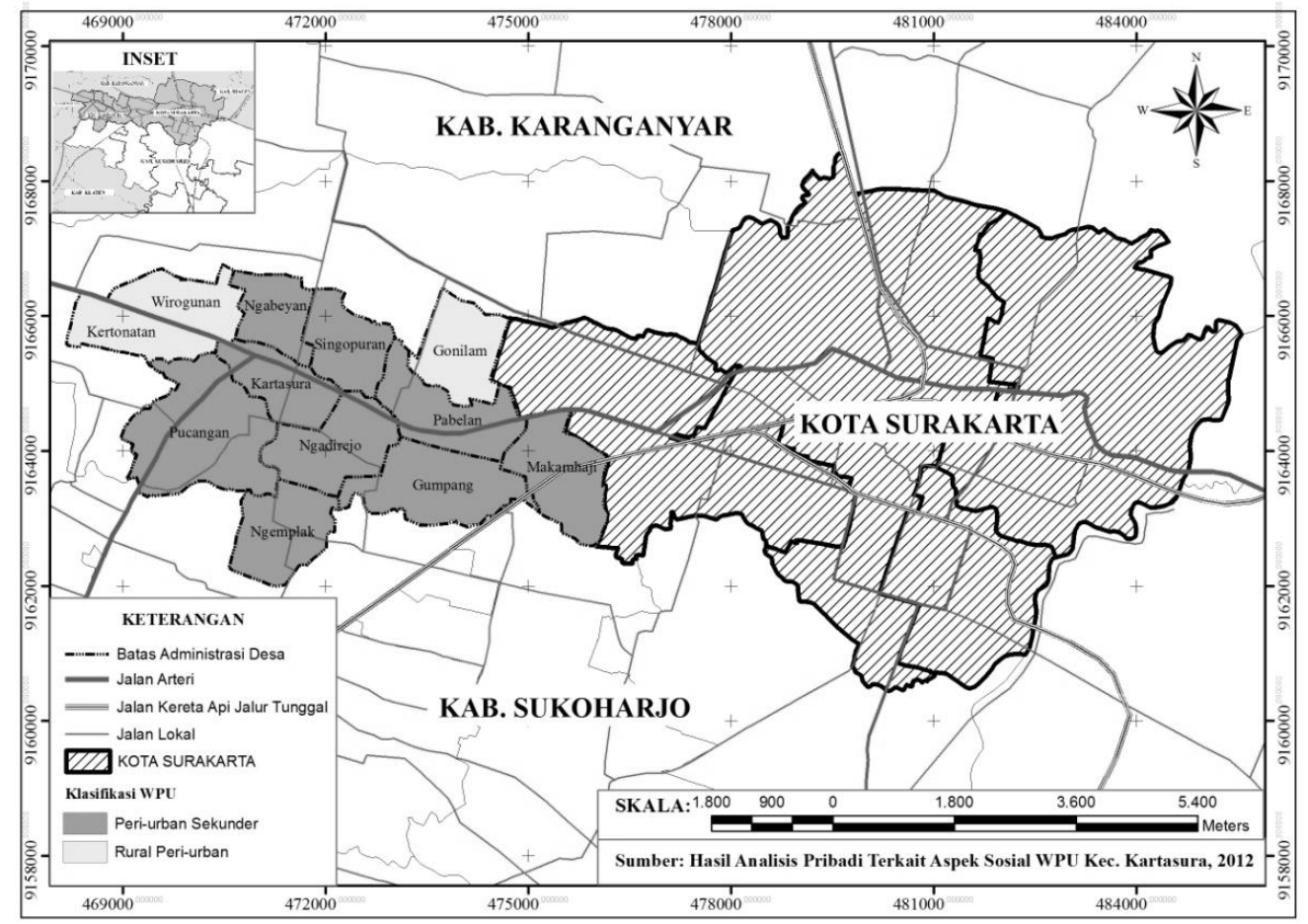

Gambar 4. Peta Tipologi Zona WPU Kecamatan Kartasura Berdasar Aspek Sosial 
Selanjutnya, proses overlay dan pembobotan yang telah disebutkan pada variable sosial, didapatkan klasifikasi yang ditunjukkan pada Gambar 4. Klasifikasi yang terbentuk hanya berjumlah dua zona yaitu zona peri-urban sekunder dengan zona rural peri-urban. Dengan demikian pada penilaian terkait aspek sosial, Kota Surakarta yang menjadi main area-nya perkembangan wilayah peri-urban tidak begitu memiliki pengaruh yang cukup besar karena klasifikasi terbesar yang terbentuk hanya pada tingkat peri-urban sekunder. Meskipun demikian, perkembangan wilayah peri-urban terkait aspek sosial bisa dikatakan lebih berorientasi mendekati Kota Surakarta dengan batas jangkauan hingga Desa Pucangan, Kelurahan Kartasura, dan Desa Ngabeyan, hanya pada Desa Gonilan yang memiliki hasil yang berbeda.

\section{Aspek Ekonomi}

Pada aspek ekonomi, pengklasifikasian tipologi zona WPU Kecamatan Kartasura akan menggunakan variable dari Desrainy,et all (2010) yaitu tingkat kesejahteraan yang dilihat melalui proporsi keluarga pra sejahtera, dimana proporsi keluarga pra sejahtera di pedesaan lebih tinggi dibanding kota. Selain itu, juga akan menggunakan proporsi pekerja sektor pertanian dan non-pertanian dari Singh (2011), untuk variable ini secara keseluruhan disebutkan bahwa pedesaan lebih didominasi oleh pekerja sektor pertanian, dan sebaliknya.

Melalui kriteria pada Tabel 1 dan data yang ada, maka didapatkan hasil seperti pada Tabel 4. Pada Tabel 4 diketahui bahwa untuk variable tingkat kesejahteraan keluarga sudah didominasi oleh zona peri-urban primer, yaitu 6 desa. Hal ini menjelaskan bahwa Kecamatan Kartasura dilihat dari tingkat kesejahteraan sudah cukup baik. Namun, Desa Ngemplak, Desa Pucangan, dan Desa Ngabeyan yang menjadi posisi rural peri-urban juga memerlukan perhatian karena ketiga desa ini memiliki tingkat kesejahteraan terendah dibanding desa lainnya di Kecamatan Kartasura. Sedangkan pada variable pekerja sektor pertanian, disebutkan bahwa desa-desa di Kecamatan Kartasura lebih terklasifikasi sebagai zona peri-urban primer hingga peri-urban sekunder. Ketidakberadaan zona rural peri-urban menjelaskan bahwa keberadaan pekerja sektor pertanian bukan menjadi prioritas bagi desa-desa di Kecamatan ini. Pekerja pertanian terbesar masih bertahan pada Desa Ngemplak yang terklasifikasi sebagai peri-urban sekunder. Dan untuk variable pekerja sektor non-pertanian, dominasi pekerjaan sektor non-pertanian berada di Kelurahan Kartasura dan Kelurahan Ngadirejo.

Tabel 4. Klasifikasi Berdasarkan Aspek Ekonomi

\begin{tabular}{r|l|c|c|c}
\hline No. & \multicolumn{1}{|c|}{ Desa/Kelurahan } & $\begin{array}{c}\text { Kesejahteraan } \\
\text { keluarga }\end{array}$ & $\begin{array}{c}\text { Pekerja } \\
\text { pertanian }\end{array}$ & $\begin{array}{c}\text { Pekerja Non- } \\
\text { pertanian }\end{array}$ \\
\hline 1 & Ngemplak & Rural PU & PU Sekunder & Rural PU \\
\hline 2 & Gumpang & PU Primer & PU Primer & PU Sekunder \\
\hline 3 & Makamhaji & PU Primer & PU Primer & PU Sekunder \\
\hline 4 & Pabelan & PU Primer & PU Primer & PU Sekunder \\
\hline 5 & Ngadirejo & PU Primer & PU Primer & PU Primer \\
\hline 6 & Kartasura & PU Sekunder & PU Primer & PU Primer \\
\hline 7 & Pucangan & Rural PU & PU Primer & PU Sekunder \\
\hline 8 & Kertonatan & PU Primer & PU Primer & PU Sekunder \\
\hline 9 & Wirogunan & PU Sekunder & PU Primer & Rural PU \\
\hline 10 & Ngabeyan & Rural PU & PU Primer & PU Sekunder \\
\hline 11 & Singopuran & PU Primer & PU Primer & PU Sekunder \\
\hline
\end{tabular}




\begin{tabular}{r|l|c|c|c}
\hline No. & \multicolumn{1}{|c|}{ Desa/Kelurahan } & $\begin{array}{c}\text { Kesejahteraan } \\
\text { keluarga }\end{array}$ & $\begin{array}{c}\text { Pekerja } \\
\text { pertanian }\end{array}$ & $\begin{array}{c}\text { Pekerja Non- } \\
\text { pertanian }\end{array}$ \\
\hline 12 & Gonilan & PU Primer & PU Primer & PU Sekunder \\
\hline \multicolumn{2}{l}{ PU = Peri-urban }
\end{tabular}

Setelah proses pengklasifikasi tiap variable, maka dilakukan pengklasifikasian aspek ekonomi secara menyeluruh dengan metode overlay dan pembobotan. Tiga zona yang terbentuk, antara lain: zona peri-urban primer meliputi 8 desa/kelurahan (Desa Kertonatan, Desa Singopuran, Desa Pabelan, Desa Gumpang, Desa Makamhaji, Desa Gumpang, Kelurahan Kartasura dan Kelurahan Ngadirejo), 3 desa (Desa Wirogunan, Desa Ngabeyan dan Desa Pucangan) masuk ke dalam zona peri-urban sekunder dan 1 desa (Desa Ngemplak) masuk ke dalam rural peri-urban., lihat Gambar 5. Keberadaan zona peri-urban primer lebih terpusat mendekati Kota Surakarta. Kota Surakarta cukup mempengaruhi perkembangan sektor ekonomi di kecamatan ini. Selain itu, aspek aksesibilitas juga terlihat berpengaruh. Hal itu bisa dilihat dari hasil Desa Ngemplak yang memiliki lokasi cukup jauh dari jalan (aksesibilitas) ternyata hanya berada pada klasifikasi rural peri-urban pada aspek ekonomi ini.

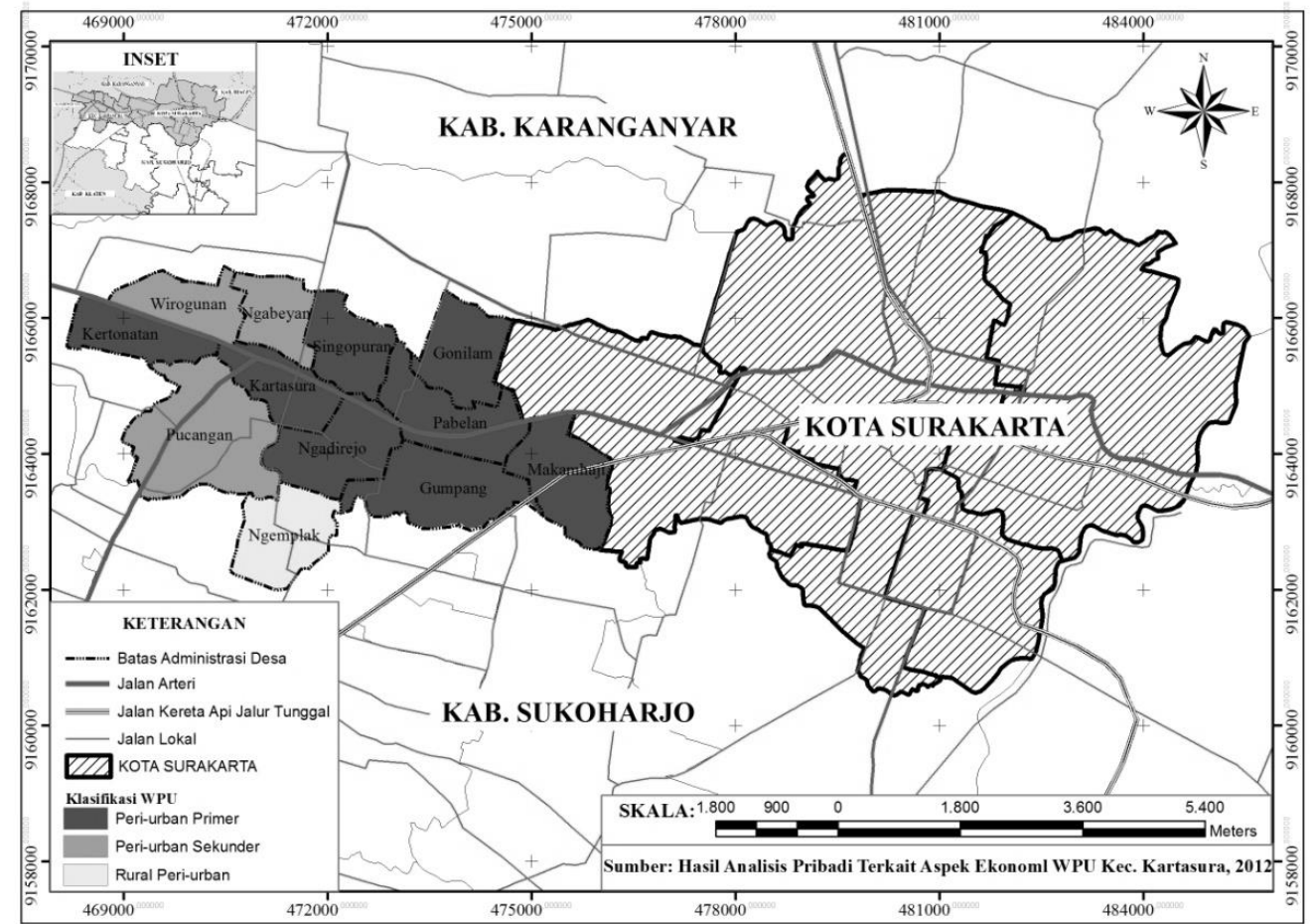

Gambar 5. Peta Tipologi Zona WPU Kecamatan Kartasura Berdasar Aspek Ekonomi

Analisis Zona Perwilayahan WPU Kecamatan Kartasura berdasar Aspek Fisik, Aspek Sosial, dan Aspek Ekonomi

Setelah didapatkan hasil klasifikasi pada tiap variable dari ketiga aspek, maka dilakukan skoring seperti Tabel 1 dan kemudian melakukan proses analisis sesuai Gambar 2. Melalui proses tersebut, pada analisis tipologi zona WPU Kecamatan Kartasura didapatkan hasil yang ditunjukkan pada Gambar 6. Tiga zona perwilayahan yang melekat pada 12 desa/kelurahan di kecamatan ini terbagi atas: zona peri-urban primer meliputi 2 
desa/kelurahan, zona peri-urban sekunder yang meliputi 8 desa, dan 2 desa terakhir termasuk dalam zona rural peri-urban.

Menurut hasil, Peri-urban primer meliputi Kelurahan Kartasura, dan Desa Pabelan dengan luas wilayah sebesar $265 \mathrm{Ha}$. Melalui metode skoring, keduanya memiliki skor pembobotan yang berbeda. Desa Pabelan yang memiliki skor 36 dan menjadi skor tertinggi membuktikan bahwa dibanding desa/kelurahan yang lain, Desa Pabelan menjadi desa yang paling dekat dengan sifat kekotaan, dengan didukung lokasi yang berbatasan langsung dengan Kota Surakarta yang bertindak sebagai urban core perkembangan WPU Kecamatan Kartasura. Baru disusul dengan Kelurahan Kartasura yang memiliki angka 35, dimana kelurahan ini dalam Perda No 2 tahun 2005 RUTRK Kecamatan Kartasura dikategorikan sebagai BWK I yang menjadi pusat aktifitas dan pemerintahan.

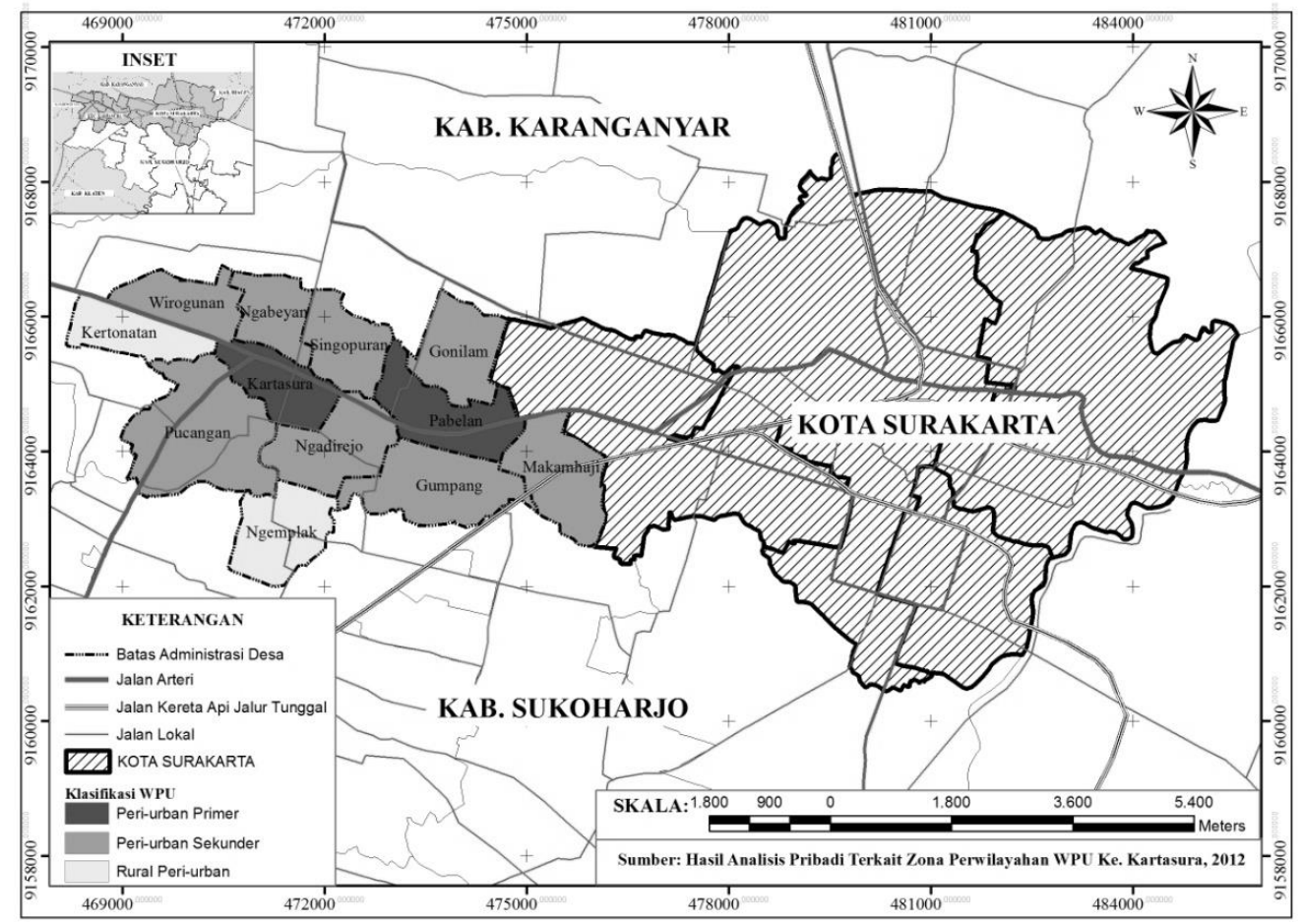

\section{Gambar 6. Peta Tipologi Zona WPU Kecamatan Kartasura Berdasar Aspek Fisik, Sosial dan Ekonomi}

Dilihat dari dominasi, zona peri-urban sekunder terdiri dari 8 desa pada WPU Kecamatan Kartasura masih terlihat mendominasi dengan jumlah desa sebanyak 8 yang meliputi: Kelurahan Ngadirejo, Desa Singopuran, Desa Gumpang, Desa Gonilan, Desa Makamhaji, Desa Pucangan, Desa Wirogunan dan Desa Ngabeyan, lihat Gambar 6. Untuk zona ini memiliki luas wilayah $1.368 \mathrm{Ha}$ dari luas total wilayah Kecamatan Kartasura 1.923 Ha. Batas skor klasifikasi pada zona ini memiliki rentang antara nilai 25 yang dimiliki Desa Ngabeyan dan Desa Gonilan hingga 29 yang dimiliki Desa Gumpang dan Kelurahan Ngadirejo. Dengan jumlah skor tersebut, apabila dilihat dari sifat wilayah, maka untuk Kelurahan Ngadirejo dan Desa Gumpang memiliki sifat-sifat mendekati sifat peri-urban primer atau lebih mengarah ke sifat kekotaan, sedangkan Desa Gonilan dan Desa Ngabeyan yang menjadi batas terdekat dari zona rural peri-urban akan menunjukkan sifat yang lebih dekat ke pedesaan. 
Daan terakhir, untuk zona rural peri-urban yang dianggap lebih dominasi sifat pedesaan hanya meliputi 2 desa saja, yaitu Desa Kertonatan dan Desa Ngemplak yang keduanya memiliki skor 24. Meskipun termasuk dalam golongan rural peri-urban, kedua desa ini memiliki skor batas terdekat dengan zona peri-urban sekunder. Dengan demikian, dapat dikatakan bahwa kedua desa ini memiliki sifat pedesaan yang lebih dekat dengan zona transisi ke sifat kekotaan. Dan zona rural peri-urban di Kecamatan Kartasura ini memiliki luasan sebesar $290 \mathrm{Ha}$, menjadi golongan dengan luasan terkecil.

Melalui proses klasifikasi tipologi zona perwilayahan WPU di Kecamatan Kartasura ini, ternyata menghasilkan karaktersitik peri-urban yang berbeda dengan WPU di daerah lain, lihat Tabel 5. Dengan batasan atau gambaran karakteristik yang terbentuk ini mampu menunjukkan bahwa ada tahapan transisi karakteristik yang terbentuk dari sifat pedesaan menuju sifat perkotaan melalui tahapan zona rural peri-urban, peri-urban sekunder dan peri-urban primer di WPU Kecamatan Kartasura. Tabel 5. Karakteristik Tipologi Zona Perwilayahan WPU Kecamatan Kartasura
Berdasar Aspek Fisik, Sosial, Dan Ekonomi

\begin{tabular}{|c|c|c|c|c|}
\hline \multirow[b]{2}{*}{ No. } & \multirow[b]{2}{*}{ Variabel } & \multicolumn{3}{|c|}{ Karakteristik } \\
\hline & & Zona Peri-Urban Primer & $\begin{array}{c}\text { Zona Peri-Urban } \\
\text { Sekunder }\end{array}$ & Zona Rural Peri-Urban \\
\hline & \multicolumn{4}{|l|}{ Aspek Fisik } \\
\hline 1. & $\begin{array}{l}\text { Penggunaan } \\
\text { Lahan }\end{array}$ & $\begin{array}{l}\text { Memiliki lahan non- } \\
\text { pertanian } 53,13 \%-100 \% \\
\text { dan sisanya merupakan } \\
\text { lahan pertanian }\end{array}$ & & $\begin{array}{l}\text { Memiliki lahan non- } \\
\text { pertanian } 23,53 \% \text { - } \\
47,52 \% \text { dan sisanya } \\
\text { sebagai lahan pertanian }\end{array}$ \\
\hline 2. & $\begin{array}{l}\text { Rasio Sarana } \\
\text { Kesehatan }\end{array}$ & $\begin{array}{llr}\text { memiliki } & \text { rasio } & \text { sarana } \\
\text { kesehatan } & \text { antara } & \text { angka } \\
5,55 \text { hingga } & 7,14 & \\
\end{array}$ & $\begin{array}{llr}\text { memiliki } & \text { rasio } & \text { sarana } \\
\text { kesehatan } & \text { antara } & \text { angka } \\
3,06 \text { hingga } 4,36 & \\
\end{array}$ & $\begin{array}{llr}\text { memiliki rasio } & \text { sarana } \\
\text { kesehatan } & \text { antara } & \text { angka } \\
1,71 \text { hingga } 3,16 & \\
\end{array}$ \\
\hline \multirow[t]{5}{*}{3.} & $\begin{array}{l}\text { Rasio } \\
\text { Pendidikan: } \\
\text { SD }\end{array}$ & $\begin{array}{lrr}\text { memiliki } & \text { rasio } & \text { sarana } \\
\text { pendidikan } & \text { SD } & \text { antara } \\
\text { angka } 0,0146 & \text { hingga } \\
0,0204 & & \\
\end{array}$ & $\begin{array}{lrr}\text { memiliki } & \text { rasio } & \text { sarana } \\
\text { pendidikan } & \text { SD } & \text { antara } \\
\text { angka } 0,0082 & \text { hingga } \\
0,0130 & & \\
\end{array}$ & $\begin{array}{lrr}\text { memiliki rasio } & \text { sarana } \\
\text { pendidikan } & \text { SD } & \text { antara } \\
\text { angka } 0,0017 & \text { hingga } \\
0,0075 & & \\
\end{array}$ \\
\hline & SMP & $\begin{array}{lcr}\text { memiliki } & \text { rasio } & \text { sarana } \\
\text { pendidikan } & \text { SMP } & \text { antara } \\
\text { angka } \geq 0,0097 & \end{array}$ & $\begin{array}{l}\text { memiliki rasio } r \text { sarana } \\
\text { pendidikan } \quad \text { SMP antara } \\
\text { angka } \geq 0,0061 \text { hingga } \\
<0,0097\end{array}$ & $\begin{array}{l}\text { memiliki rasio } \begin{array}{r}\text { sarana } \\
\text { pendidikan }\end{array} \text { SMP antara } \\
\text { angka } 0 \text { hingga } 0,0013\end{array}$ \\
\hline & SMA & $\begin{array}{lcr}\text { memiliki } & \text { rasio } & \text { sarana } \\
\text { pendidikan } & \text { SMA } & \text { antara } \\
\text { angka } \geq 0,0096 & \text { hingga } \\
0,0143 & & \\
\end{array}$ & $\begin{array}{l}\text { memiliki rasio sarana } \\
\text { pendidikan SMA antara } \\
\text { angka } \geq 0,0053 \text { hingga } \\
0,0080\end{array}$ & $\begin{array}{l}\text { memiliki rasio sarana } \\
\text { pendidikan SMA pada } \\
\text { angka 0 (tidak memiliki } \\
\text { sarana SMA) }\end{array}$ \\
\hline & $\begin{array}{l}\text { Perguruan } \\
\text { Tinggi }\end{array}$ & $\begin{array}{l}\text { memiliki rasio } r \text { sarana } \\
\text { pendidikan } \\
\text { tinggi } \geq 0,0027\end{array}$ & - & $\begin{array}{l}\text { memiliki rasio sarana } \\
\text { pendidikan SMP pada } \\
\text { angka } 0 \text { (tidak memiliki } \\
\text { sarana SMA) hingga } \leq \\
0,0009\end{array}$ \\
\hline & \multicolumn{4}{|l|}{ Aspek Sosial } \\
\hline 2. & $\begin{array}{l}\text { Kepadatan } \\
\text { Penduduk }\end{array}$ & $\begin{array}{l}\text { memiliki angka kepadatan } \\
\text { penduduk } 5.098,44 \text { hingga } \\
11.567,16 \mathrm{jiwa} / \mathrm{km} 2\end{array}$ & $\begin{array}{lr}\text { memiliki } & \text { angka } \\
\text { kepadatan penduduk dari } \\
3.020 \text { hingga } 4.845,11 \\
\text { jiwa/km2 }\end{array}$ & $\begin{array}{lr}\text { memiliki } & \text { angka } \\
\text { kepadatan } & \text { penduduk } \\
\text { sebesar } & 2.121,18 \text { hingga } \\
2.728,45 \text { jiwa/km2 }\end{array}$ \\
\hline 3. & $\begin{array}{l}\text { Rasio } \\
\text { Kelahiran } \\
\text { Penduduk }\end{array}$ & $\begin{array}{l}\text { memiliki rasio kelahiran } \\
\text { pada kisaran } 21,63 \text { hingga } \\
24,84\end{array}$ & $\begin{array}{l}\text { memiliki rasio kelahiran } \\
\text { pada kisaran angka } 12,28 \\
\text { hingga } 16,82\end{array}$ & $\begin{array}{l}\text { memiliki rasio kelahiran } \\
\text { pada kisaran angka } 4,5 \\
\text { hingga } 7,37\end{array}$ \\
\hline 4. & $\begin{array}{l}\text { Rasio } \\
\text { Kematian }\end{array}$ & $\begin{array}{l}\text { memiliki rasio kematian } \\
\text { pada kisaran } 3,84 \text { hingga }\end{array}$ & $\begin{array}{l}\text { memiliki rasio kematian } \\
\text { pada kisaran angka } 5,31\end{array}$ & $\begin{array}{l}\text { memiliki rasio kematian } \\
\text { pada kisaran angka } 7,28\end{array}$ \\
\hline
\end{tabular}




\begin{tabular}{|c|c|c|c|c|}
\hline \multirow[b]{2}{*}{ No. } & \multirow[b]{2}{*}{ Variabel } & \multicolumn{3}{|c|}{ Karakteristik } \\
\hline & & Zona Peri-Urban Primer & $\begin{array}{c}\text { Zona Peri-Urban } \\
\text { Sekunder }\end{array}$ & Zona Rural Peri-Urban \\
\hline & Penduduk & 4,99 & hingga 6,29 & hingga 7,98 \\
\hline 5. & $\begin{array}{l}\text { Rasio Beban } \\
\text { Tanggungan }\end{array}$ & 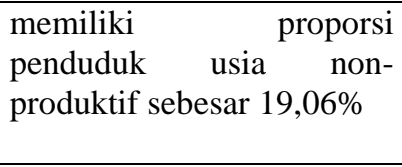 & 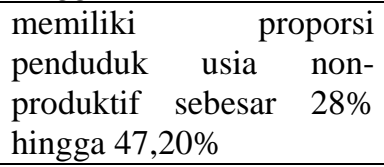 & $\begin{array}{l}\text { memiliki proporsi } \\
\text { penduduk usia non- } \\
\text { produktif sebesar } 50,32 \% \\
\text { hingga } 58,38 \%\end{array}$ \\
\hline 6. & Kualitas SDM & $\begin{array}{l}\text { memiliki jumlah penduduk } \\
\text { terdidik sebesar } 53,20 \% \\
\text { hingga } 71,21 \%\end{array}$ & $\begin{array}{lr}\text { memiliki } & \text { jumlah } \\
\text { penduduk } & \text { terdidik } \\
\text { sebesar } 35,44 \% & \text { hingga } \\
47,76 \% & \\
\end{array}$ & $\begin{array}{l}\text { memiliki jumlah } \\
\text { penduduk terdidik sebesar } \\
6,61 \% \text { hingga } 8,43 \%\end{array}$ \\
\hline 7. & $\begin{array}{l}\text { Heterogenitas } \\
\text { Penduduk }\end{array}$ & - & $\begin{array}{l}\text { karakteristik angka rasio } \\
\text { heterogenitas antara } \\
1,08 \% \text { hingga } 10,43 \% .\end{array}$ & - \\
\hline & Aspek Ekonomi & & & \\
\hline 8. & $\begin{array}{l}\text { Tingkat } \\
\text { Kesejahteraan } \\
\text { Keluarga }\end{array}$ & $\begin{array}{l}\text { memiliki proporsi keluarga } \\
\text { pra sejahtera sebesar } \\
2,74 \% \text { hingga } 8,98 \%\end{array}$ & $\begin{array}{lrr}\text { memiliki } & \text { proporsi } \\
\text { keluarga } & \text { pra } & \text { sejahtera } \\
\text { sebesar } & 15,35 \% & \text { hingga } \\
27,30 \% & & \\
\end{array}$ & $\begin{array}{llr}\text { memiliki } & \text { proporsi } \\
\text { keluarga } & \text { pra } & \text { sejahtera } \\
\text { sebesar } & 33,91 \% & \text { hingga } \\
45,69 \% & & \\
\end{array}$ \\
\hline 9. & $\begin{array}{l}\text { Mata } \\
\text { Pencaharian } \\
\text { Sektor } \\
\text { Pertanian } \\
\end{array}$ & $\begin{array}{l}\text { memiliki penduduk yang } \\
\text { bermata pencaharian di } \\
\text { sektor pertanian sebesar } \\
0 \% \text { hingga } 34,78 \%\end{array}$ & $\begin{array}{l}\text { memiliki penduduk yang } \\
\text { bermata pencaharian di } \\
\text { sektor pertanian sebesar } \\
54,46 \%\end{array}$ & - \\
\hline 10. & $\begin{array}{l}\text { Mata } \\
\text { Pencaharian } \\
\text { Sektor Non- } \\
\text { Pertanian }\end{array}$ & $\begin{array}{l}\text { memiliki jumlah penduduk } \\
\text { yang bermata pencaharian } \\
\text { pada sektor non-pertanian } \\
\text { sebesar } 100 \%\end{array}$ & $\begin{array}{l}\text { memiliki jumlah } \\
\text { penduduk yang bermata } \\
\text { pencaharian pada sektor } \\
\text { non-pertanian sebesar } \\
76,70 \% \text { hingga } 99,91 \%\end{array}$ & $\begin{array}{l}\text { memiliki jumlah } \\
\text { penduduk yang bermata } \\
\text { pencaharian pada sektor } \\
\text { non-pertanian sebesar } \\
45,54 \% \text { hingga } 65,22 \%\end{array}$ \\
\hline
\end{tabular}

\section{Kesimpulan}

Transformasi fisik, sosial, dan ekonomi yang terjadi pada WPU Kartasura akibat perkembangan eksternal dari urbancore, Kota Surakarta ternyata memberikan klasifikasi yang berbeda jika hanya melihat dari satu aspek saja. Batas bias terkait pengaruh sifat kekotaan oleh kota inti dan kelestarian sifat pedesaan akibat wilayah pedesaan di sisi lain, pada desa/kelurahan di Kecamatan Kartasura menjadi lebih tegas melalui analisis dari ketiga aspek, yang meliputi faktor-faktor: penggunaan lahan, sarana kesehatan, sarana pendidikan, kepadatan penduduk, kualitas SDM, angka kelahiran dan kematian, rasio beban tanggungan, heterogenitas, kesejahteraan keluarga, dan mata pencaharian.

Di sisi lain, pengklasifikasian yang dilakukan ternyata mampu menjelaskan jangkauan pengaruh aktivitas kekotaan dari Kota Surakarta, dimana pengaruh yang ada hanya sampai batas zona peri-urban sekunder dengan menempatkan Desa Kertonatan yang memiliki lokasi terjauh dari Kota Surakarta ke dalam zona rural peri-urban. Selain itu, lokasi Desa Ngemplak yang tidak dilalui jaringan jalan utama dan aksesibilitas yang memadai, juga menjadikan desa ini masuk dalam kategori zona rural peri-urban. Hal ini membuktikan bahwa, transformasi fisik, sosial, dan ekonomi di WPU Kartasura tidak hanya dipengaruhi oleh pengaruh urbancore-nya (Kota Surakarta) saja, tetapi juga terpengaruh oleh aksesibilitasnya. 


\section{Klasifikasi Tipologi Zona Perwilayahan Wilayah Peri-Urban di Kecamatan Kartasura, Kabupaten Sukoharjo}

\section{Daftar Pustaka}

Anonim. 2000. "PP No. 129 Tahun 2000 Tentang Persyaratan Pembentukan Dan Kriteria Pemekaran, Penghapusan Dan Penggabungan Daerah.” 15 Juni 2012. http://hukumonline.com

Anonim. 2005. "Peraturan Daerah Kabupaten Sukoharjo Nomor 2 Tahun 2005," dalam Lembaran Daerah Kabupaten Sukoharjo Tahun 2005 Nomor 2. 07 Desember 2011. http://dprdsukoharjokab.go.id/file_download/Microsoft\%20Word\%20-\%20No.2\%202005.pdf

Anonim. 2009. "Pertumbuhan Ekonomi dan Pengentasan Kemiskinan di Indonesia." 14 Juni 2012. http://wongdesmiwati.files.wordpress.com/2009/10/pertumbuhan-ekonomi-dan-pengentasankemiskinan-di-indonesia-_analisis-ekonometri_.pdf

Anonim. 2009. RTRW Kabupaten Sukoharjo Tahun 2009. Sukoharjo: Bappeda Kabupaten Sukoharjo SK Menteri Pertanian No.837/KPTS/UM/II/1980 dan No.683/KPTS/UM/VII/1981

Anonim. 2011. "Petilasan," dalam kerajaan nusantara .6 April 2012. http://www.kerajaannusantara.com/id/surakarta-hadiningrat/petilasan/

Anonim. 2011. Kecamatan Kartasura dalam Angka 2011. Sukoharjo: Badan Pusat Statistik

Data Podes Jawa Tengah pada Tahun 2003

Desrainy, Louise MP et al. 2010. "Karakteristik Wilayah Peri-Urban pada Metropolitan Jabodetabekjur,” dalam Working Paper Regional and Planning Research Group ITB. No. 02. 10 Desember 2012. http://www.sappk.itb.ac.id/pwd/images/wp02pwd2010.pdf

Khaerudin. 2002. "Studi Identifikasi Karakteristik dan Perkembangan Pedesaan Tertinggal Kabupaten Batang." Tugas Akhir S1 Jurusan Perencanaan Wilayah dan Kota, Universitas Diponegoro, Semarang.

Longelay, Paul A. et al. 2005. Geographical Information System and Science. UK: John Wiley \& Sons, Ltd.

Prianti, Martina dan Nurul Fitriani. 2011. "Usia Produktif Dorong Pertumbuhan Ekonomi Indonesia," dalam Indonesia Finance Today. 14 juni 2012. http://www.indonesiafinancetoday.com/read/14701/UsiaProduktif-Dorong-Pertumbuhan-Ekonomi

Profil Desa dan Kelurahan di Kecamatan Kartasura Tahun 2011

Rudiarto, Iwan. Tanpa Tahun. Spatial Assessment of Rural Resources and Livelihood Development In Mountain Area of Java: A case from Central Java- Indonesia. Jerman: Margraf Publisher.

Singh, Rana P.B. 2011. "Changing Rural Landscape in The Peri-Urban Zone of Varanasi and Strategies for Sustainable Planning,” dalam IFLA APR CLC International Symposium. Hlm. 169-184.

Yunus, Hadi Sabari. 2008. Dinamika Wilayah Peri-Urban: Determinan Masa Depan Kota. Yogyakarta: Pustaka Pelajar. 